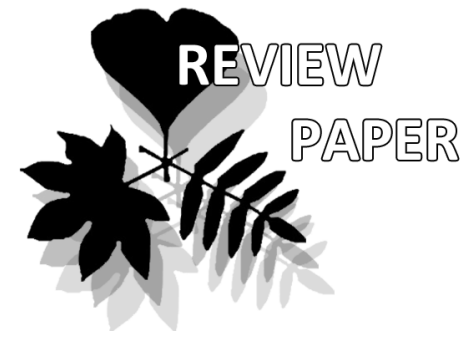

\title{
Functional Aspects of the Origin and Subsequent Evolution of Cotyledons in Seed Plants
}

\author{
Dmitry D. Sokoloff ${ }^{1} *$, Paula J. Rudall ${ }^{2}$, Richard M. Bateman ${ }^{2}$ \\ \& Margarita V. Remizowa ${ }^{1}$
}

Dmitry D. Sokoloff ${ }^{1 *}$

e-mail: sokoloff-v@yandex.ru

Paula J. Rudall ${ }^{2}$

e-mail: p.rudall@kew.org

Richard M. Bateman ${ }^{2}$

e-mail: r.bateman@kew.org

Margarita V. Remizowa ${ }^{1}$

e-mail: remizowa@yahoo.com

${ }^{1}$ Department of Higher Plants, Biological Faculty, Moscow State University 12, 1, Leninskie Gory, 119991 Moscow, Russia

${ }^{2}$ Royal Botanic Gardens Kew, Richmond, Surrey, TW9 3DS, U.K.

* corresponding author

Manuscript received: 20.07 .2015

Review completed: 18.09 .2015

Accepted for publication: 29.09.2015

Published online: 30.09 .2015

\begin{abstract}
A B S T R A C T
In most seed plants, cotyledons formed within the seed act as haustorial organs, as well as playing a key role in releasing the shoot apex from the seed coat on germination. Emergence of the shoot apex often results from asymmetric intercalary growth of the cotyledon bases. This process avoids the principal spatial constraint on germination in seed plants, wherein the plumule is surrounded by cotyledons whose tips should be in contact with nutritive tissues. Cotyledons are commonly viewed as a synapomorphy of the seed-plant lineage and as the modified first leaves of a seedling. However, intercalary growth, which is crucial for the cotyledon's role in releasing the plumule, had not yet been acquired by foliage leaves of the earliest seed plants. We explore the possibility that the program of intercalary growth in leaves first evolved in cotyledons and was subsequently recruited for foliage leaves in the seed-plant lineage. We also discuss whether early seed plants already possessed haustorial cotyledons.
\end{abstract}

K e y w o r d s : embryo development, haustorium, gymnosperms, intercalary growth, megaphyll, seed germination, spatial constraint

\section{P E 3 Ю M E}

Соколов А.А., Рудами П.Аж., Бэйтман Р.М., Ремизова М.В. Функциональные аспекты происхожАения и эволюции семядолей семенных растений. Семядоли большинства семенных растений выполняют гаусториальные функции, а также играют важную роль в высвобождении апекса побега из семени при его прорастании. Высвобождение апекса побега часто идет за счет асимметричного интеркацярного роста оснований семядолей. Этот процесс позволяет обойти ключевое пространственное ограничение при прорастании семенных растений, связанное с тем, что почечка окружена семядолями, верхушки которых связаны с питательными тканями семени. Семядоли обычно считают синапоморфией семенных растений и видоизмененными первыми Аистьями проростка. ОАнако интеркалярный рост, столь важный Аля роли семядолей в высвобожАении почечки, еще не был приобретен Аистьями Аревнейших семенных растений. Из-за отсутствия прямых свидетельств мы обсужАаем четыре гипотетически возможных сценария происхождения семяАолей. Мы рассматриваем возможность того, что интеркалярный рост впервые появился у семядолей, а затем эта программа развития распространилась и на обычные Аистья семенных растений. С Аругой стороны, возможно, что Аревнейшие семенные растения еще не имели гаусториальных семядолей.

Ключевые слова: гаусторий, голосеменные растения, интеркалярный рост, мегафимл, прорастание семени, пространственное ограничение, развитие зародыша

\section{Cotyledons of seed plants as haustorial structures}

Cotyledons are embryonic structures, widely defined as the first pair of leaves (or single leaf or leaf whorl) that develops at the first node of the primary axis of the sporophyte (e.g., Bower 1882, Goebel 1905, 1932, von Guttenberg 1966, Mestre \& Guédès 1983). However, in the narrower sense, cotyledons are also regarded by some authors as fundamentally haustorial organs that are restricted to seed plants (Niklas 2008). A primary homology between the first leaves of lycopsids, ferns (and allied groups), progymnosperms and seed plants appears at best questionable because of the postulated independent evolution of leaves in these lineages (reviewed by Kenrick \& Crane 1997,
Boyce \& Knoll 2002, Boyce 2005, Niklas 2008, Sanders et al. 2009, Galtier 2010). Although the single origin of microphylls in lycopsids is widely accepted, recent estimates of the number of origins of so-called 'megaphylls' range from two to nine (Tomescu 2009), and vigorous debates continue among evolutionary-developmental geneticists regarding the level of process homology among leaves (for early examples compare Harrison et al. 2005, Bowman et al. 2006).

The haustorial function represents an important feature of embryo/seedling evolution. Haustorial cotyledon tips absorb nutrients from the female gametophyte (in gymnosperms) or from the endosperm (in angiosperms). Although in many cases the haustorial function of cotyledons has been postu- 
lated using indirect evidence, direct experimental studies have demonstrated this role of the cotyledons in diverse taxa, including the comparatively early-divergent extant seed plant Ginkgo biloba (Bulard 1952, Ball 1959). The cotyledons do not represent the only haustorial organs in seed plants - for example, the suspensor is haustorial at earlier stages of seed development - but the haustorial role of the cotyledons is typically crucial at seed germination. Embryo development in organic association with gametophyte tissues has often been cited as one of the key innovations that most likely appeared in a stem lineage of land plants (e.g., Graham \& Wilcox 2000, Graham et al. 2000). A symplastic connection is always absent between sporophyte and gametophyte tissues (Ligrone et al. 1993), so specialized structures are invariably required in order to transfer nutrients. In most extant gymnosperms (except Gnetum and Welwitchia; see below), as well as in earlydivergent extant angiosperms, the cotyledon tips act as haustoria through which nutrients enter the young sporophyte at seed germination (e.g., Tillich 1990, Ye et al. 1993, Friedman et al. 2012, Dörken 2014). Admittedly, seed structure is highly diverse across angiosperms, and in some taxa the cotyledons accumulate nutrients rather than act as haustorial structures. However, the storage function is regarded as a derived condition in angiosperms (e.g., Grushvitzky 1963). Even if all nutrients are accumulated in the embryo by the time of germination, the cotyledons fulfil the same haustorial function at certain stages of seed development (e.g., Johansson \& Walles 1994). In contrast, in extant land plants that do not belong in the seed-plant lineage, the leaf organs (when present) do not fulfil a haustorial role (e.g., Goebel 1905, 1932, Niklas 2008).

We believe that, despite rarely being discussed, cotyledon origin could represent a key event in the early evolution of seed plants. The fossil record indicates that seed plants first appeared in the Devonian period (Pettitt \& Beck 1968, Rothwell et al. 1989, Gerrienne et al. 2004, DiMichele et al. 2006, Prestianni \& Gerrienne 2010) and extensively diversified during the Carboniferous, but direct data on embryo or seedling morphology are notably missing for these pteridosperms of the Devonian and Carboniferous. The typical absence of an embryo from anatomically preserved seeds of early seed plants remains enigmatic but probably indicates that embryogenesis occurred long after seed-coat formation and ovule/seed dispersal (e.g., Chamberlain 1935, Emberger 1942, Meyer 1958, Taylor et al. 2009). In the absence of direct observational data, we present indirect arguments to infer multiple hypotheses about the early evolution of seedplant cotyledons. Indirect reasoning is currently the only approach available to explore several key events in evolution of land plants - not only the origin of the cotyledon but also, for example, the origin of endogenous root branching (Timonin 1989).

\section{Embryo polarity in seed plants - the principal spatial constraint at seed germination}

Two principal types of embryo polarity can be recognized across the land plants (e.g., Niklas 2008). In exoscopic polarity (Fig. 1A, B), the apical pole of the embryo develops close to the tip of the archegonium (i.e., the neck end). In endoscopic polarity (Fig. 1C, D), the apical pole of the embryo develops close to the base of the archegonium (i.e., the venter end). By definition, in extant vascular plants, the apical pole gives rise to a primary shoot and the resulting shoot system ultimately bears sporangia, whereas in bryophytes, the apical pole develops a single sporangium.

Embryos of all extant seed plants are endoscopic. Even though angiosperms and a few gymnosperms (the gnetaleans Gnetum and Welwitschia) lack unambiguous archegonia, the spatial arrangement of their embryos with respect to other structures (especially the ovule micropyle) and comparisons with other gymnosperms clearly indicate endoscopic embryo orientation; the suspensor always lies at the apical (micropylar) pole. This orientation is already evident in the oldest known (uppermost Carboniferous or lowermost Permian) fossil seed-plant embryos that demonstrably contain cotyledons (Mapes et al. 1989). Bryophytes - the basal grade of land plants - all possess exoscopic embryos (at least in extant taxa), which suggests that this condition is plesiomorphic in the land-plant clade. Although optimization of this character is problematic among free-sporing vascular plants (largely due to the exoscopic condition observed in Psilotum, Equisetum and some ferns), the endoscopic condition appears to be a derived but not universally retained condition (i.e., a 'synapomorphic tendency') of the tracheophyte clade (Niklas 2008, Niklas \& Kutschera 2009). Thus, existing phylogenetic evidence suggests that embryos were likely
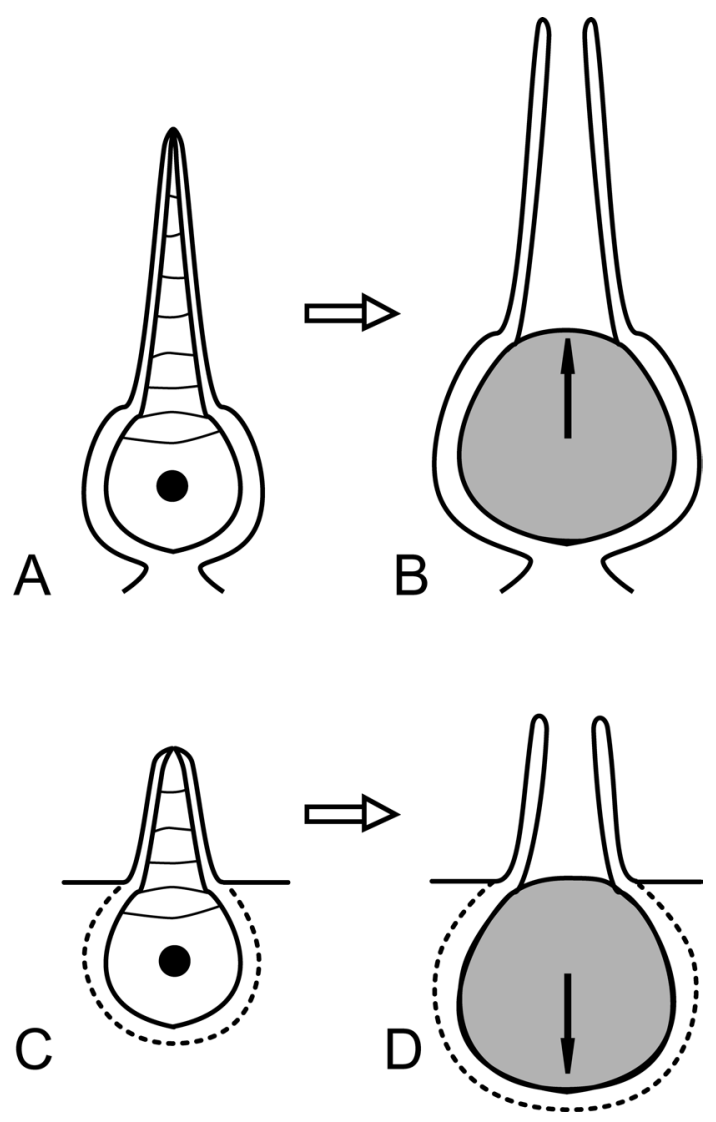

Figure 1 Diagrams of unfertilized (A, C) and fertilized (B, D) archegonia showing exoscopic (A, B) and endoscopic (C, D) embryo development. Black circle = egg nucleus; grey = embryo; arrows indicate embryo polarity facing toward its apical (sporangial) pole 
already endoscopic in the ancestors of seed plants. If so, this dramatic polarity shift pre-dated the equally fundamental polarity transition from proximal to distal microspore/pollen grain germination that occurred in the pteridosperm stem lineage (Rudall \& Bateman 2007).

Among extant seed plants, the suspensor, primary root and shoot apex follow a linear arrangement, and the primary shoot and root develop directly opposite each other (e.g., Troll 1943, Groff \& Kaplan 1988, Gifford \& Foster 1989). The archegonia (or the egg cell in the angiosperm embryo sac) are located in the micropylar region of the ovule. These features, coupled with endoscopic embryo polarity, allow easy release of the primary root at seed germination. In stark contrast, there is a serious spatial constraint for growth and release of the primary shoot (Sokoloff et al. 2013). In gymnosperms, basal angiosperms and eudicots, the shoot apex is normally surrounded by two (or more) cotyledons. If the cotyledons fulfil a haustorial function at seed germination, direct growth and emergence of the shoot apex is highly problematic. Even though the embryos and seedlings of the earliest seed plants are unknown, it is likely that similar spatial constraints were already in place. Indeed, both a well-developed and nutritive female gametophyte and a well-developed seed coat appear to represent plesiomorphic conditions in seed plants. A common, and clearly archaic, way of avoiding this spatial constraint during seed germination is by intercalary, and often asymmetric, growth of the cotyledon bases (for detailed discussion see Sokoloff et al. 2013, 2014). The elongation of the cotyledons pushes the embryonic axis outside the seed coat, subsequent emergence of the primary shoot occurring between the cotyledon bases. Intercalary growth is a characteristic feature of cotyledons in seed plants, including gymnosperms. For example, according to Spurr (1949), the numerous cotyledons of Pinus develop almost entirely by intercalary growth. We highlight a need for a comprehensive comparative developmental analysis of intercalary cotyledon elongation on germination across seed plants, as cotyledon elongation could in theory occur due to cell elongation only. In the specialized case previously described in detail in Allium cepa, where the cotyledon simultaneously fulfils haustorial and photosynthetic functions, two distinct zones of intercalary cotyledon elongation are present (Sachs 1863, Esau 1977). Apart from the cotyledons, intercalary growth also often occurs in the hypocotyl of seed plant seedlings, but this elongation does not assist emergence of the primary shoot.

Some seed plants - both angiosperms (e.g., some Apiaceae, Podophyllaceae, Ranunculaceae) and gymnosperms (some cycads and some Araucaria) - possess basally united cotyledons that form a long and narrow cotyledonary tube due to intercalary growth that occurs upon seed germination (Seward \& Ford 1906, Dorety 1909, 1919, Haccius 1952, 1953, Barykina 1971, 1995, Haines \& Lye 1979, Titova 2006). In such cases, as in more common types of seed germination, intercalary growth allows release of the shoot apex from the seed coat (often also burying the shoot deeper in the soil - a feature that is particularly typical of geophytes). On the other hand, expansion forming the cotyledonary tube creates a constraint to growth of the primary shoot, because its internal canal is too narrow; it can even disappear via postgenital fusion. Growth occurs after physical rupture or disintegration of the tube. In Araucaria bidwillii, for example, the cotyledonary tube is cut off near the base of the plumule by a ring of cork (Seward \& Ford 1906).

\section{Early evolution of seed-plant seedlings: general speculations}

The haustorial role of cotyledons at seed germination is a key feature that should be encompassed by any plausible scenario of embryo and seedling evolution in early seed plants. The taxonomic distribution of this feature is precisely documented in extant plants, whereas the fossil record adds disappointingly few relevant facts to the story. There are, for example, several detailed descriptions of embryos and seedlings of fossil conifers, but they fall within the range of variation demonstrated for extant members of this group (Stockey 1975, 1977, Stockey \& Taylor 1978, Mapes et al. 1989).

So far, the oldest known seedling of a non-coniferalean gymnosperm probably belongs to the 'higher pteridosperm' Glossopteris (Pant \& Nautiyal 1987). Its cotyledons are dichotomously divided and differ strongly from entire foliage leaves with reticulate venation. This cotyledon morphology may support a syntelomic origin through fusion of bifurcating telomes, but the overall significance of this seedling with regard to large-scale reconstructions of cotyledon evolution is unclear because of the relatively young age of the fossil (Permian) and the comparatively derived phylogenetic position of glossopterids inferred from all previous morphological cladistic analyses. Most importantly, there is no direct evidence of a haustorial role for the cotyledons at germination, because they were epigeal and remains of seed coat or endosperm were not documented in this fossil. However, given that glossopterids are widely recognized as putative angiosperm relatives ('anthophytes'), this fossil seedling could prove useful in discussing embryo evolution in flowering plants. Krassilov (1972) described a seedling and various stages of embryo development in another nonconiferalean fossil gymnosperm, the Jurassic Karkenia asiatica. If Karkenia is indeed closely related to Ginkgo (Zhou 2009), then a more massive suspensor and especially the occurrence of developed embryos in seeds attached to maternal plants of Karkenia offer a remarkable contrast with those of Ginkgo (Krassilov 1989). Bauer et al. (2013) provided detailed illustrated descriptions of seedlings of a Triassic ginkgophyte that shows affinities with Baiera. The seedlings are dicotylar, and the cotyledon behaviour is similar to that observed in the extant Ginkego.

Evidence from cotyledons of extant plants is sensitive to fundamental differences between published phylogenetic tree topologies for seed plants (reviewed by Hilton \& Bateman 2006, Rudall \& Bateman 2007, Doyle, 2008, 2013). For example, following the non-cladistic phylogenetic reconstructions of Meyen (1987) and Krassilov (1997), the closest common ancestors of extant seed plants could be as ancient as the earliest pteridosperms of the mid-late Devonian period (Figs. 2, 3). In contrast, most recent morphological cladistic studies (Fig. 4) suggest that the extant 


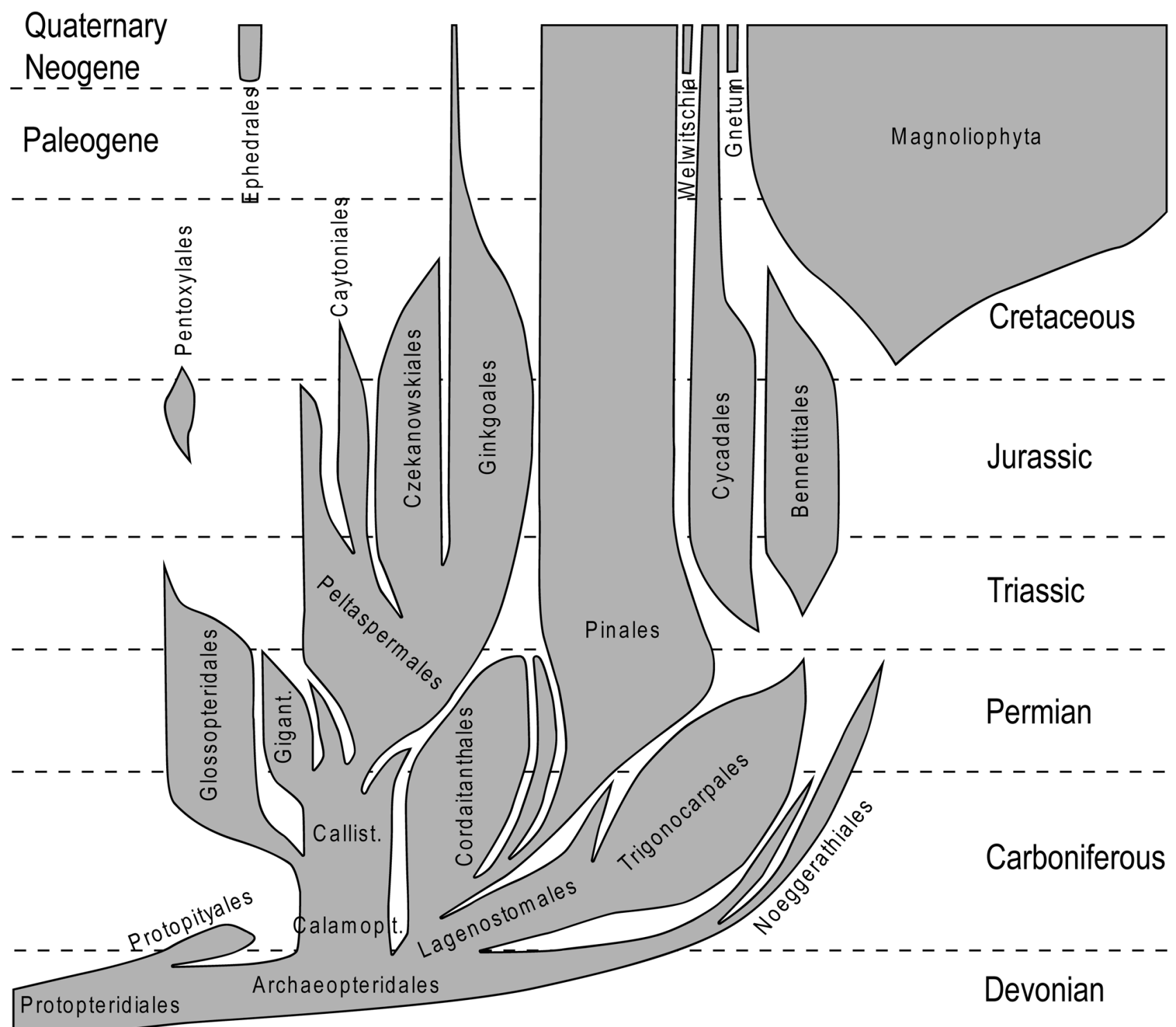

Figure 2 Diagram of phylogenetic relationships among seed plants, redrawn in a simplified form from fig. 11 of Meyen (1987). According to this view, the closest common ancestor of all extant seed plants was not younger than the early Carboniferous or Devonian/ Carboniferous boundary. If the possession of haustorial cotyledons is a uniquely derived synapomorphy of extant seed plants, then the cotyledons must have originated in plants with very archaic megaphyllous vegetative leaves. Traditional names of some orders are preferred in the figure (e.g., Glossopteridales rather than Arberiales) to facilitate comparisons with Figs. 3 and 4 . Note that the early fossil record of Gnetales (e.g., Crane 1996, Krassilov 2009) became well known only after publication of Meyen (1987)

seed plants belong to a clade that excludes the paraphyletic assemblage of 'lower pteridosperms' (e.g., Hilton \& Bateman 2006, Doyle 2008, 2013). The framework provided by these phylogenetic studies has allowed us to formulate at least four contrasting scenarios of early cotyledon evolution, as discussed in subsequent sections of this paper. In proposing these scenarios, we assumed that the embryo of ancestral seed plants was already endoscopic (with root and shoot/telome apex located at opposite poles) and explored all logically possible variants. If future studies reveal inadequacies in all the four scenarios, then our assumptions regarding the nature of the ancestral embryo may require modification.

Among progymnosperms - a paraphyletic group that includes the likely closest relatives of seed plants - the fossil genus Eddya (Beck 1967) could represent a juvenile progymnosperm allied to Archaeopteris. Although the root- stem transition is not fully preserved in Eddya, it seems that the plant resembled most seed plants in possessing a primary root that developed on a pole opposite the main shoot. If the basic features of embryo polarity are plesiomorphic in the seed-plant lineage, then the spatial constraints involving release of the primary axis were already significant at the stage of the acquisition of heterospory (Fig. 5). It is universally accepted that the acquisition of heterospory preceded the origins of ovules in the seed-plant lineage, though the fossil record documenting the reproductive biology of these heterosporous ancestors is highly imperfect (but see Bateman \& DiMichele 1994, Marshall \& Hemsley 2003). However, as heterospory appeared several times during the course of higher-plant evolution, with repeated acquisition of a similar set of characters, apparently in a similar sequence (Bateman \& DiMichele 1994), important predictions can be made regarding the female gameto- 
phytes of the seed-plant ancestor. It probably possessed large megaspores with well-developed sporoderm containing sporopollenin. Megaspore germination was probably proximal, with release of small-celled tissue-bearing archegonia, whereas the nutrients were concentrated in a gametophytic tissue that remained within the sporoderm. If the apex of the primary axis was oriented toward the centre of the former megaspore, a constraint would have existed to the growth and release of the primary axis (Fig. 5).

Extant and (where data exist) extinct heterosporous plants belonging to other vascular plant lineages (Salviniales, Marsileales, Isoetales, Selaginellales) avoid a similar constraint because, in their embryos, the first root and shoot apices are not necessarily located at opposite poles. In addition, there is often a special haustorial organ (a foot, which is apparently an organ sui generis). The first leaf, shoot and root apices and the foot develop on different sides of the embryo (e.g., Groff \& Kaplan 1988, Gifford \& Foster 1989). Due to the asymmetry of the embryo, the shoot apex can be readily released, even with endoscopic development.

\section{Scenario 1: Seedlings of Gnetales retained plesiomorphic features}

Seedlings of the gnetaleans Gnetum (at least G. gnemon) and Welwitschia are unique among extant seed plants in the consistent presence of a special outgrowth of the seedling axis (usually termed a feeder) that fulfils a haustorial function (Bower 1881, 1882, Pearson 1929, Butler et al. 1973, Bornman et al. 1979). In the case of Gnetum, the foot also facilitates release of the rest of the embryo from the seed coat (Bower 1882). A similar structure occurs in a Cretaceous fossil seedling of a plant closely related to Welwitschia (Rydin et al. 2003). Conversely, Dilcher et al. (2005) questioned the cotyledon homologies proposed by Rydin et al., and did not report a feeder in seedlings of another fossil related to Welwitschia. The cotyledons of Gnetum and Welwitschia do not act as haustoria on germination. Given the definition of cotyledons as fundamentally haustorial organs, the cotyledonary nature of the first phyllomes in these plants is problematic unless they are haustorial during embryo development within the seed. Although the haustorial outgrowth resembles the foot of some free-sporing tracheophytes, it differs in two respects: comparatively late initiation near the stage of seed germination, and flexible environmental control of the side on which the outgrowth is initiated (Bower 1881, 1882, Bornman et al. 1979). Some authors highlighted similarities between the gnetalean feeder and haustorial organ in a few selected monocot seedlings and interpreted them in terms of possible evolutionary homologies (e.g., Mestre \& Guédès 1983). However, we follow here the more parsimonious view that the haustorial organ in monocot seedlings is always formed by the morphological tip of the cotyledon (e.g., Tillich 1995, 2007).

Scenario 1 hypothesizes that the feeder of Welwitschia and Gnetum is a plesiomorphic condition inherited from the earliest Devonian seed plants (Ye et al. 1993). This archaic condition was substituted later in seed-plant evolution by a novel type of seed germination that involves the cotyledons.
Scenario 1 is problematic for several reasons of sufficient gravity that we do not consider it plausible. Gnetales form the basal lineage of extant seed plants in only a few molecular analyses (e.g., Mathews 2009) and in no morphological analysis (Figs. 2-4). According to both molecular and morphological data, Gnetales occupy a comparatively long phylogenetic branch that is embedded within the crown group of seed plants, though their inferred precise position is highly sensitive to the type of data and method of tree-building used (Burleigh \& Mathews 2004, Graham \& Iles 2009). The embedded position of Gnetales makes it much more parsimonious to accept the absence of haustorial cotyledons as a reversal to the primitive state rather than a genuine plesiomorphy (Fig. 4). Most other features characteristic of Gnetum and Welwitschia (such as the occurrence of vessels and paracytic stomata, tetrasporic female gametophyte, absence of archegonia) are commonly regarded as apomorphies at the seed-plant scale. Although the sequential acquisition of apomorphic states inherent in heterobathmy (Takhtajan 1991) is a common feature of plant evolution, we believe that it is unlikely to explain the unusual morphology of gnetalean seedlings.

Scenario 1 postulates that the earliest seed plants lacked cotyledons as haustorial structures. It implies that, at a certain stage of seed-plant evolution, the first leaves of the primary axis acquired new functions and were transformed into cotyledons (Ye et al. 1993). According to Ye et al. (1993), the cotyledons (and seeds) appeared more than once in several evolutionary lineages. Such a transformation apparently lacks an adaptive advantage (admittedly, functional implications are also unclear for proposed scenarios seeking to explain the origins of some other important plant characters). Indeed, this transformation would exacerbate the spatial problems encountered at seed germination, because the shoot apex is hidden between the cotyledon bases. If the early seed plants already possessed adaptations that allowed release of the shoot apex in seeds possessing an endoscopic embryo, why were these adaptations not retained during evolution in some more advanced evolutionary lineages? In Welwitschia and Gnetum, initiation of the feeder late in embryo development (soon after germination in Welwitschia: Bornman et al. 1979), as well as environmental control of its direction of growth, make it unlikely that these features are ancestral. It is also of interest that the cotyledons of Welwitschia play a particular role in liberating the shoot apex from the endosperm, especially at early stages of germination; they are not merely passively liberated due to the elongation of the feeder (Bower 1881). Interestingly, neither shoot nor root of the Welwitschia seedling emerge from the micropylar side of the seed. Rather, they rupture the seed envelopes (Butler et al. 1973). Such rupturing of seed envelopes was problematic in many early pteridosperms due to occurrence of substantial mechanical tissues in the seed coat.

The cotyledons of Ephedra may act as haustoria during seed germination, but this behaviour is unstable and they may emerge before nutrients of the female gametophyte have been fully consumed. The mode of seed germination depends on its location relative to gravity, at least in some 


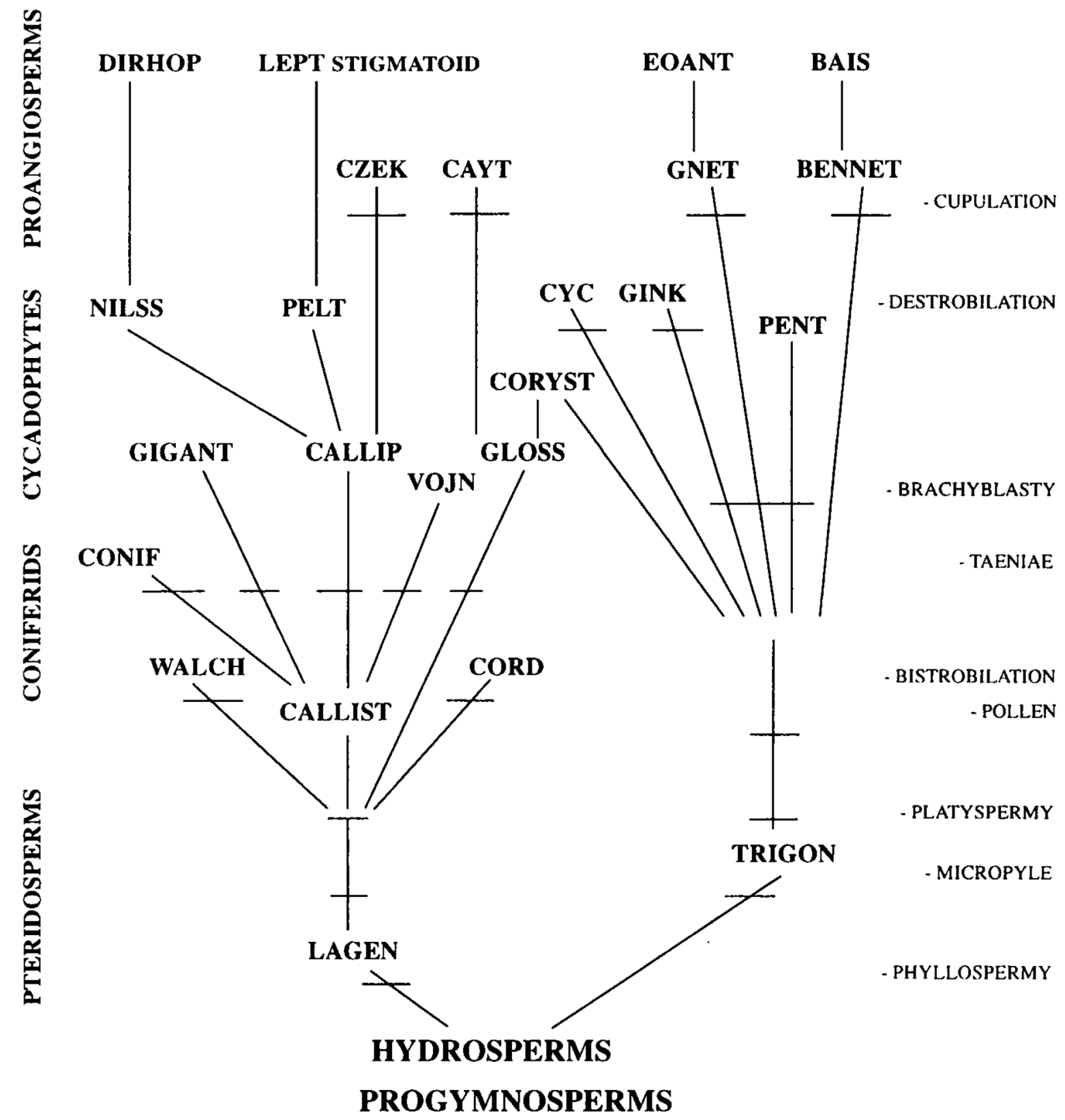

Figure 3 Phylogenetic relations among and between gymnosperms and angiosperms, with horizontal dashes marking the characters (right) appearing in more than one clade (Krassilov 1997). Although the phylogenetic hypothesis of Krassilov (1997) differs considerably from that of Meven (Fig. 2), these two non-cladistic studies share the concept of a relatively ancient closest common ancestor of all extant seed plants. As with the phylogeny of Meyen, a single origin of the haustorial cotyledon was only possible in archaic seed ferns. However, as can be seen from the right-hand part of the diagram, it is possible that Krassilov would have accepted the concept of multiple origins of cotyledons

species (Bower 1882, but see Scatizzi 1937). Bower (1882) and Pearson (1929) highlighted the absence of a feeder in Ephedra and Bower (1882) speculated that the remains of suspensor and nucellus could facilitate transfer of nutrients in seedlings with early emergent cotyledons. In contrast, Vasilchenko (1937, 1960) observed a small (vestigial or incipient?) feeder-like outgrowth in those Ephedra seedlings that were characterized by early emergence of the cotyledons. A detailed study of Scatizzi (1937) did not reveal the occurrence of an one-sided feeder in Ephedra (though a different species was studied from that explored by Vasilchenko); instead, an envelope surrounding the young root "velo germinale" (?= Wurzelkalotte of Siegert 1989, Schneckenburger 1993; hypocotyl cap of Ball 1956) was found to be haustorial. Interestingly, the behaviour of the micropylar part of the seed coat in Ephedra as described by Scatizzi (1937) resembles the seed operculum of the earlydivergent angiosperm order Nymphaeales.

In the context of Scenario 1, future evidence on the embryo morphology and phylogenetic position of Bennettitales may prove important. Taylor et al. (2009) reported the occurrence of a feeder-like structure in embryos of some bennettites, though their actual seed germination was not documented. Given the tree topology of Doyle (2008), the occurrence of a feeder in bennettites might be interpreted as an argument in support of the idea of a plesiomorphic nature of a feeder in seed plants, because bennettites and Gnetales belong to very distantly related clades in this 


\section{A. Hilton \& Bateman (2006)}

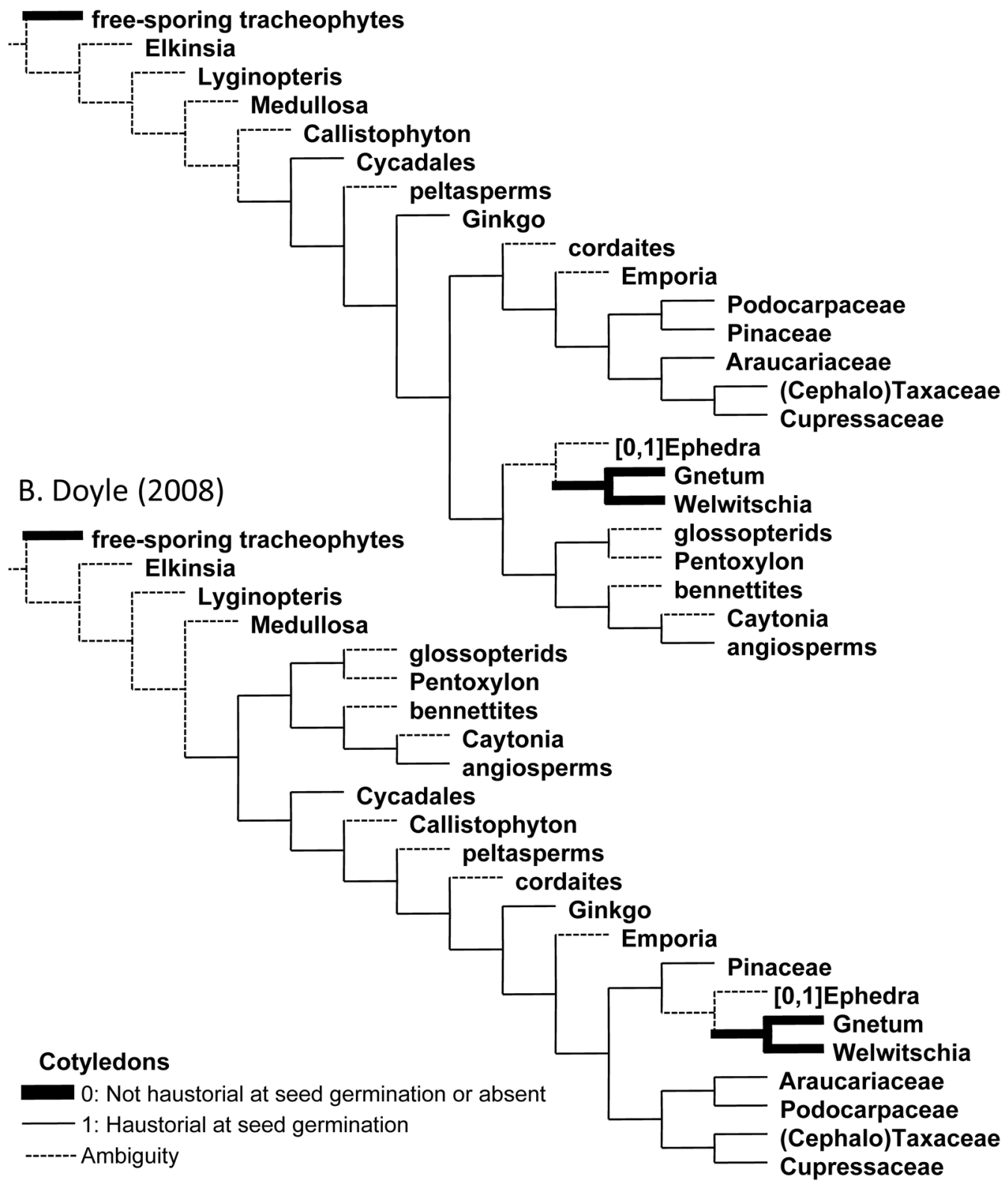

Figure 4 Simplified trees inferred from cladistic analyses of extant and fossil seed plants with maximum parsimony reconstructions of the possession of haustorial cotyledons. The angiosperms are scored as having ancestrally haustorial cotyledons, based on the evidence of widespread occurrence of this feature in early-divergent flowering plants. Subsequent evolution of contrasting cotyledon functions within angiosperms is not considered here. A. Tree topology from Hilton \& Bateman (2006) based on non-molecular characters only. B. One of 18 trees from Doyle's (2008) morphology-based analyses, with relationships among extant taxa constrained according to a molecular phylogenetic topology. Although topologies (A) and (B) differ in many important details, both allow (but do not require!) much later origin of haustorial cotyledons than the non-cladistic trees of Meyen (Fig. 2) and Krassilov (Fig. 3)

topology (see Fig. 4B). Given the topology of Hilton \& Bateman (2006), the putative bennettitalean feeder does not play an important role in discussions at the scale of seed plants, because the bennettites and Gnetales belong to the same large clade in this topology (Fig. 4A).

\section{Scenario 2: Cotyledons are older than typical foliage leaves}

Scenarios 2, 3 and 4 all imply that haustorial cotyledons appeared as a synapomorphy of a clade comprising all extant seed plants, which is the most parsimonious reconstruction of character evolution based on most current phy- logenies (Fig. 4). They all imply that a common ancestor of all extant seed plants developed a straight endoscopic embryo possessing more than one cotyledon, haustorial cotyledonary tips, and intercalary elongation of the cotyledon bases at seed germination. The three scenarios differ primarily in the proposed timing of cotyledon origin and degree of homology between cotyledons and foliage leaves.

Scenario 2 implies that haustorial cotyledons (with intercalary elongation at seed germination) were already present in the Upper Devonian hydrasperman pteridosperms. According to this view, in the absence of embryo asymmetry or a feeder/foot, early members of the seed-plant 


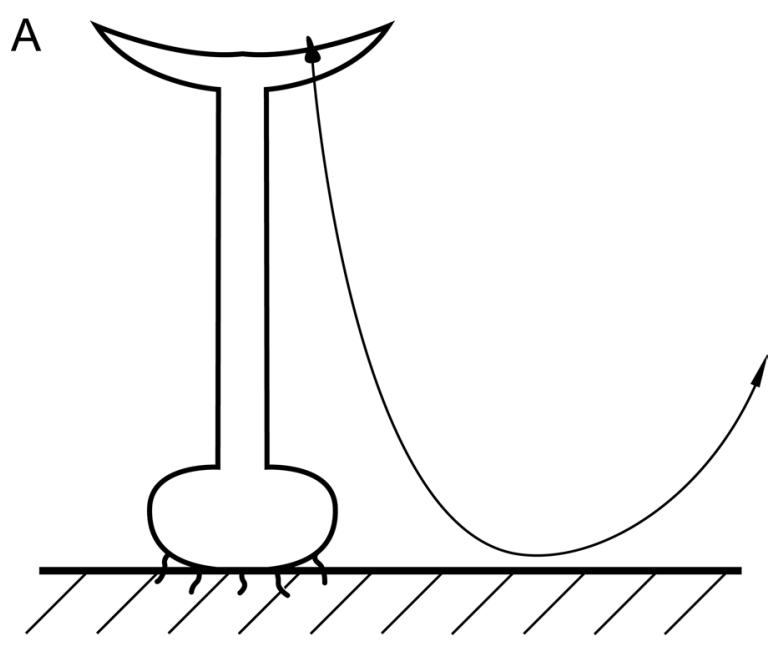

B
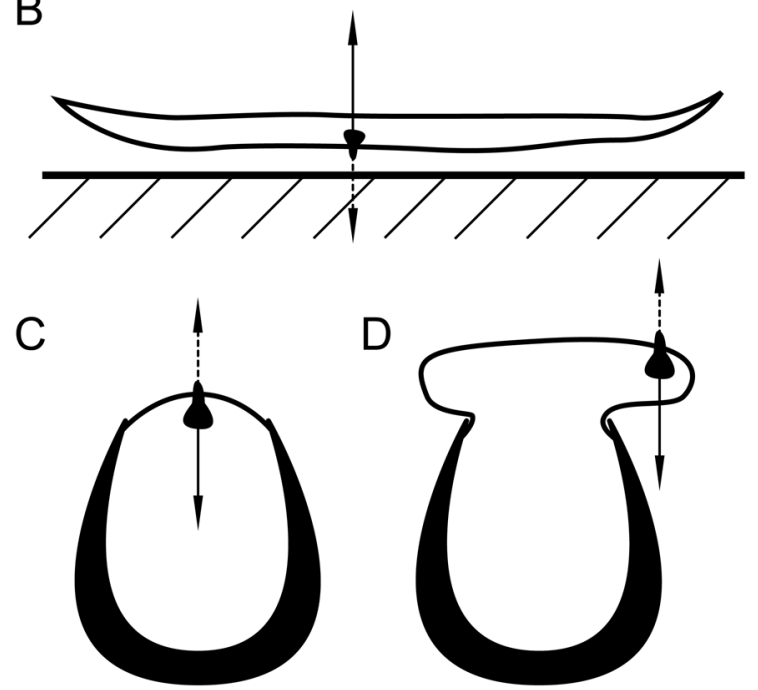

fertilized archegonium

apical pole growth

1 possible root pole growth

Figure 5 Diagrams of hypothetical patterns of early growth of sporophytes developing from bipolar endoscopic embryos in extinct free-sporing members of the seed-plant stem group. A, B homosporous stage; C, D - heterosporous stage (the distally ruptured megaspore wall shown in black). Each diagram shows a female (or possibly bisexual in A, B) gametophyte with the position of a fertilized archegonium indicated. Arrows indicate directions of apical (sporangial) and root-pole elongation. As the comparative timing of root origin is unknown, root direction is more speculative than other aspects of the figure. A - telomic gametophyte with a receptacular distal archegoniophore (similar gametophytes have been described in some Devonian tracheophytes). B - transverse section of thalloid gametophyte with archegonia on its lower side. C - female gametophyte not released from the megaspore wall. Special adaptations are required to release the apical pole of the sporophyte. $\mathrm{D}$ - female gametophyte partially released; no spatial constraint exists for growth of the young sporophyte lineage acquired two or more cotyledons as lateral organs, facilitating transfer of nutrients into the young sporophyte as well as release of the apex at germination. This scenario postulates that, as in all extant gymnosperms, the female gametophyte - a source of nutrients for the developing seedling - remains inside the seed coat throughout the process of seed germination. Scenario 2 appears congruent with the views of Chamberlain (1935; see his fig. 33).

In the context of Scenario 2, it is revealing to place cotyledon evolution within the general framework of leaf evolution in seed plants. Most recent accounts agree that multiple groups of vascular plants independently acquired megaphyllous leaves - that is, leaves derived from systems of branching telomes (reviewed by Kenrick 2002, Tomescu 2009). The seed-plant lineage was one of these groups. The oldest known leaves of seed plants are large structures with a basally bifurcating rachis and numerous distal pinnulae that show clear evidence of transformation from systems of telomes. There is strong evidence that, in all lineages that acquired megaphyllous leaves, the most archaic forms possessed exclusively marginal growth of the pinnulae; diffuse growth appeared much later in evolution. Most extant seed plants are characterized by extensive intercalary growth of the leaf base or petiole - a condition that appears unlikely to be ancestral.

Regarding the earliest Devonian seed plants for which Scenario 2 postulates the presence of cotyledons, they possessed leaves that represent arguably the most primitive forms among seed plants. If the cotyledons of these plants already fulfilled a haustorial function and played an important role in release of the shoot apex from the female gametophyte due to intercalary elongation of their bases, then the cotyledons were much more 'advanced' structures in terms of leaf evolution than were the vegetative leaves of the same plants. Moreover, it is difficult to imagine a process of reduction of large megaphylls in statu nascendi into compact cotyledons, though we cannot wholly exclude the possibility of rapid, saltational transformations sensu Bateman \& DiMichele (2002). Unmodified telomes could act as organs of photosynthesis, even though this function was facilitated by the acquisition of megaphyllous leaves. In contrast, in order to function at seed germination, cotyledons should already be specialized to a certain degree. These theoretical considerations highlight the problems in interpreting the cotyledons as modified leaves. Within the framework of Scenario 2, it is possible that cotyledons evolved simultaneously with - if not earlier than - typical seed-plant leaves. In this case, some developmental features of cotyledons (e.g., intercalary elongation) could have been recruited at a later stage of vegetative leaf evolution.

If cotyledons appeared at least simultaneously with vegetative leaves, were these two structures fully homologous? Galtier (2010) controversially concluded that the large megaphylls of seed plants are not homologous with what he perceived as the small megaphylls of progymnosperms. Similar arguments could be made for some fossil fern-relatives such as cladoxylaleans. Rather, the large megaphylls are derived from entire branch systems bearing multiple small megaphylls. However, it appears unlikely that a young sporophyte immediately started to develop lateral 
branches with small megaphylls (or their precursors). It is more likely that, as in Eddya, the primary axis first produced small megaphyll precursors and only later developed large branches. It is plausible to hypothesize that these simple early-formed structures were transformed into cotyledons. An even more radical and speculative hypothesis could be proposed, specifically that the ancestral cotyledons did not represent syntelomic structures but rather were fundamentally different from megaphyllous leaves (for example, they could have evolved by evolutionary-developmental 'duplication' of a haustorial foot that resulted in the origins of a radial symmetry of the embryo - a feature that is now viewed as being characteristic of seed plants). These differences were obscured during subsequent evolutionary events that 'homogenized' the developmental regulation of lateral structures of different origins.

Comparative morphology provides several lines of evidence in favour of a direct homology between cotyledons and leaves (Spurr 1949, Kaplan \& Cooke 1997): (1) cotyledons occur in the same positions on the shoot as do the leaves; (2) both cotyledons and leaves possess buds in their axils; (3) cotyledon development is very similar to leaf development; (4) cotyledons resemble leaves in mature morphology; and (5) intermediates occur in some taxa between cotyledons and foliage leaves (Goebel 1905, 1932). These arguments do not exclude the possibility of the origin of cotyledons and leaves in seed plants from small and large megaphylls, respectively, their similarity increasing only during the subsequent course of evolution. However, the presence of buds in the axils of the cotyledons is a feature that renders problematic the 'foot duplication' hypothesis.

The 'foot duplication' hypothesis recalls some aspects of earlier views of Lyon (1902), who regarded the monocotylar embryo as a primitive condition in seed plants in general and in angiosperms in particular (see also Tzvelev 2000), the original cotyledon thus being homologous with the haustorial foot of free-sporing plants. The current phylogenetic framework makes the idea of primitiveness of monocotylar embryos in angiosperms far from parsimonious.

\section{Scenarios 3 and 4: 'Non-seed' early pteridosperms}

In general, the major problem with Scenario 2 is that it postulates the occurrence of functionally specialized cotyledons at a very early stage of seed-plant evolution, before acquisition of typical megaphyllous foliage leaves. Scenarios 3 and 4 are proposed as attempts to 'postpone' the proposed timing of cotyledon origins, in order to make their homologies with foliage leaves more plausible. Scenarios 3 and 4 both imply that the earliest 'seed plants' (such as Devonian pteridosperms) did not develop embryos within the seed coat, and that the absence of collected early seed fossils containing embryos (cf. Long 1975, Rothwell \& Scheckler 1988, Hilton 1998) does not reflect either a taphonomic artefact or embryo development that routinely occurred immediately before germination. These scenarios propose that the distal part of the female gametophyte was ultimately released from the seed coat, probably through the micropyle (or due to complete splitting and shedding of the seed coat in response to swelling of the female gametophyte?) This process took place on the ground rather than on the maternal plant, and the embryo of the nextgeneration sporophyte was at the earliest stage (perhaps zygotic) at the moment of release of the female gametophyte. As soon as the embryo has developed outside the seed coat, the use of the term 'seed' becomes problematic. More importantly, this mode of embryo development created no spatial constraint for growth of the embryonic apex. The haustorial role was probably performed entirely by the suspensor. In extant plants, the suspensor plays a primary haustorial role at early stages of embryo development, before appearance of the cotyledons. Its function as a haustorium creates a spatial problem for root emergence, but it is possible that root development was delayed (as in extant cycads: Dortey 1909, 1919).

At first, the late emergence of the female gametophyte differs from what we know of other heterosporous plants, where the release of the distal part of the gametophyte, when present, took place prior to development of archegonia. The proposed scenario for early seed plants would then be regarded as an extreme heterochrony. Such a heterochronic shift can be explained by the adaptive significance of pollination occurring on the earliest possible stage. This scenario is analogous to the extreme development of stigmas that occurs in some wind-pollinated angiosperm trees and shrubs (e.g., Corylus), maturing at the stage when the ovary and ovules are not yet perfectly formed.

The concept of partial release of the female gametophyte appears congruent with the view of Taylor et al. (2009) that some early seed plants produced embryos that were formed rapidly and soon escaped the protective integuments. As stated by Emberger (1942), the consistent absence of embryos in the earliest known fossil 'seeds' possibly does not represent a taphonomic artefact but indicates something important in the nature of these 'seeds'. Note, however, that the idea of rapid embryo development in the earliest seed plants is not congruent with the slow development reported in many extant gymnosperms.

Scenarios 3 and 4 provide sufficient time for early evolution of foliage leaves without the occurrence of haustorial cotyledons. Both scenarios imply that the lowermost leaves ultimately acquired new haustorial functions and evolved into cotyledons. Their haustorial behaviour appears adaptive, because the cotyledons were able to substitute the haustorial role of the suspensor at certain ontogenetic stages, thereby allowing release of the main root. However, Scenarios 3 and 4 differ in other important respects.

\section{Scenario 3: Early recruitment of leaves}

This scenario implies that the recruitment of leaves as haustorial organs occurred relatively early in seed-plant evolution, when the leaves were still at a 'primitive' stage and did not acquire the characteristic intercalary growth. The cotyledons, when they first appeared, were connected to the female gametophyte released from the seed coat. Later in the course of evolution, the cotyledons started to undergo intercalary elongation, which facilitated embryo development within the seed coat and allowed easy release of the 
plumule. The ability to achieve intercalary growth thus first appeared in cotyledons and was subsequently included in the developmental program of foliage leaves.

\section{Scenario 4: Late recruitment of leaves}

In this scenario, intercalary growth of foliage leaves appeared before the acquisition of a haustorial role by the lowermost leaves of the sporophyte. Thus, the cotyledons $\mathrm{ab}$ initio were able to undergo intercalary growth. The occurrence of cotyledons, as in the previous scenario, allowed embryo development within the seed coat and its easy release on germination. In both scenarios, once the embryo started to develop within the seed coat, there was no need for gametophyte release from the seed. The cladistic trees (Fig. 4) apparently do not contradict either scenario (3 and 4, as well as Scenario 2), but the non-cladistic trees (Figs. 2, 3) do not allow Scenario 4 - at least, if a single origin of cotyledons is assumed. This is because these trees imply that the most recent common ancestor of all extant seed plants belonged to the earliest pteridosperms, or even to progymnosperms (Figs. 2, 3). Present fossil data are of limited assistance in choosing between Scenarios 3 and 4 (and other comparable scenarios), because the oldest known embryo that developed within the seed (Stidd \& Cosentino 1976, Taylor et al. 2009) is relatively young (Middle Pennsylvanian) and, more importantly, belonged to the cordaites a gymnosperm group that has a 'derived' foliage leaf morphology and is widely regarded as a stem-group of conifers (e.g. Florin 1951, Hilton \& Bateman 2006, Doyle 2013).

\section{CONCLUDING REMARKS}

We emphasize that the question of cotyledon origins in seed plants is far from being satisfactorily resolved. This topic - which sadly is seldom discussed in modern botanical literature - merits greater attention, as it is highly relevant to the problem of early evolution of seed-plant leaves and the seed-plant life cycle. We hypothesize that, contrary to traditional opinion, cotyledons are only partially homologous with vegetative leaves (Scenario 2), and that the similarities of these two categories of organ increased during the course of evolution (Scenarios 2 and 3). It is likely that the occurrence of intercalary leaf growth during development was a key feature of seed-plant evolution and that cotyledons should therefore be considered in all discussions of this phenomenon.

One of most intriguing remaining questions is explaining the putative origin of cotyledons as opposite or whorled organs. Indeed, based on the distribution of embryo morphologies across current phylogenies, it is likely that the cotyledons were ancestrally whorled or opposite. On the other hand, spiral phyllotaxy appears ancestral for foliage leaves of seed plants. If cotyledons are indeed modified basal leaves, why did they appear as whorled or opposite rather than spiral (but see Lodkina 1988)? This question, which once again raises the issue of the ambiguous homologies between bona fide leaves and cotyledons, requires further detailed investigation.

We propose several ways of testing these provocative ideas:
(1) An extensive search for well-preserved seedlings of fossil early seed plants.

(2) Detailed comparison of genetic control of cotyledon and leaf development in all extant lineages of gymnosperms. Studies of the model angiosperm Arabidopsis have highlighted some differences in developmental controls in vegetative leaves versus cotyledons (Chandler 2008), so it now becomes important to determine whether similar differences occur in gymnosperms.

(3) Inferring the impact of intercalary elongation of the rachis and petiole in the earliest seed plants, ideally assisted by the discovery of better-preserved Devonian fossils (cf. Rothwell et al. 1989).

(4) Detailed analysis of seedling anatomy and functional aspects of seed germination in different species of Ephedra compared with those of other later-divergent Gnetales and conifers, aimed at determining whether the peculiar seed haustorium of Welwitschia and Gnetum is a primitive or (more likely) a derived feature. It is intriguing that Celis \& Avalos (2013) reported cryptocotylar and hypogeal germination in Gnetum leyboldii but did not mention a feeder in this species. These data need to be confirmed, because neither an illustration nor a comparison with G. gnemon was provided.

(5) Accumulating more direct observations on patterns of transport of nutrients in gymnosperms, especially in Gnetales. In particular, it would be interesting to investigate possible haustorial function of cotyledons that might operate prior to seed germination.

Whatever the answers to the above questions, we have become convinced that the much more widely discussed criteria of absolute seed size (e.g., Raven 1999) and comparative embryo size (e.g., Forbis et al. 2002; Linkies et al. 2010) are by no means the only physical constraints on seedling competence.

\section{ACKNOWLEDGEMENTS}

We are grateful to Yu.E. Alexeev, A.G. Platonova, A.C. Timonin and N.E. Zavialova for helpful discussions and assistance in obtaining literature and to an anonymous reviewer for helpful suggestions. The study was partially supported by the Russian Foundation for Basic Research (projects 14-04-01412 and 14-04-31271).

\section{LITERATURE CITED}

Ball, E. 1956. Growth of the embryo of Ginkgo biloba under experimental conditions. I. Origin of the first root of the seedling in vitro. American Journal of Botany 43: 488-495.

Ball, E. 1959. Growth of the embryo of Ginkgo biloba under experimental conditions. III. Growth rates of root and shoot upon media absorbed through the cotyledons. American Journal of Botany 46: 130-139.

Barykina, R.P. 1971. Peculiarities of first stages of ontogeny of Podophyllum emodi Wall. and P. peltatum L. Botanicheskii Zhurnal 56: 921-931 (in Russian). [Барыкина Р.П. 1971. Особенности первых этапов онтогенеза Podophyllum emodi Wall. и P. peltatum L. // Ботанический журнац. T. 56. C. 921-931].

Barykina, R.P. 1995. Morphological and ecological patterns of somatic evolution in the family Ranunculaceae Juss. Abstract of DSc Thesis (Biology). Moscow State University, Moscow, 46 pp. (in Russian). [Барыкина Р.П. 1995. Морфолого- 
экологическииие закономерности соматической эвоАюции в семействе мютиковых (Ranunculaceae Juss.). Автореф. Аисс. ... Аокт. биол. наук. М., 1995. 46 с.].

Bateman, R.M. \& W.A. DiMichele 1994. Heterospory: the most iterative key innovation in the evolutionary history of the plant kingdom. Biological Reviews 69: 345-417.

Bateman, R.M. \& W.A. DiMichele 2002. Generating and filtering major phenotypic novelties: neoGoldschmidtian saltation revisited. In: Developmental genetics and plant evolution (Q.C.B. Cronk, R.M. Bateman \& J.A. Hawkins, eds.), pp. 109-159, Taylor \& Francis, London.

Bauer, K., L. Grauvogel-Stamm, E. Kustatscher \& M. Krings 2013. Fossil ginkgophyte seedlings from the Triassic of France resemble modern Ginkgo biloba. BMC Evolutionary Biology 13: 177.

Beck, C.B. 1967. Eddya sullivanensis, gen. et sp. nov., a plant of gymnospermic morphology from the Upper Devonian of New York. Palaeontographica B 121: 1-22.

Bornman, C.H., V. Butler \& W.A. Jensen 1979. Welwitschia mirabilis: fine structure of the germinating seed. I. Orientation. Zeitschrift für Pflanzenphysiologie 91:189-196.

Bower, F.O. 1881. On the germination and histology of the seedlings of Welwitschia mirabilis. Quarterly Journal of Microscopical Science 21: 15-30.

Bower, F.O. 1882. The germination and embryogeny of Gnetum gnemon. Quarterly Journal of Microscopical Science 87: 278-298.

Boyce, C.K. 2005. Patterns of segregation and convergence in the evolution of fern and seed plant leaf morphologies. Paleobiology 31: 117-140.

Boyce, C.K. \& A.H. Knoll 2002. Evolution and developmental potential and the multiple independent origins of leaves in Paleozoic vascular plants. Paleobiology 28: 70-100.

Bulard, C. 1952. Culture aseptique d'embryons de Ginkgo biloba: Rôle des cotylédons dans l'absorption du sucre et la croissance de la tige. Comptes rendus hebdomadaires des séances de l'Académie des sciences 235: 739-741.

Burleigh, J.G. \& S. Mathews 2004. Phylogenetic signal in nucleotide data from seed plants: implications for resolving the seed-plant tree of life. American Journal of Botany 91: 1599-1613.

Butler, V., C.H. Bornman \& R.F. Evert 1973. Welwitschia mirabilis: Morphology of the seedling. Botanical Garette 134: 52-59.

Celis, G. \& G. Avalos 2013. Acclimation of seedlings of Gnetum leyboldii Tul. (Gnetaceae) to light changes in a tropical rain forest. International Journal of Tropical Biology and Conservation 61: 1859-1868.

Chamberlain, C.J. 1935. Gymnosperms. Structure and evolution. University of Chicago Press, Chicago. 484 pp.

Chandler, J.W. 2008 . Cotyledon organogenesis. Journal of Experimental Botany 59: 2917-2931.

Crane, P.R. 1996. The fossil history of the Gnetales. International Journal of Plant Sciences 157 (Suppl.): S50-S57.

Dilcher, D.L., M.E. Bernardes-De-Oliveira, D. Pons \& T.A. Lott 2005. Welwitschiaceae from the Lower Cretaceous of northeastern Brazil. American Journal of Botany 92: 1294-1310.

DiMichele, W.A., T.L. Phillips \& H.W. Pfefferkorn 2006. Paleoecology of Late Paleozic pteridosperms from tropical Euramerica. Journal of the Torrey Botanical Society 133: 83-118.

Dorety, H.A. 1909. Vascular anatomy of the seedling of Microcycas calocoma. Botanical Gazette 47: 139-147.

Dorety, H.A. 1919. Embryo and seedling of Dioon spinulosum. Botanical Garette 67: 251-257.
Dörken, V.M. 2013. Morphology, anatomy and vasculature in leaves of Ginkgo biloba L. (Ginkgoaceae, Ginkgoales) under functional and evolutionary aspects. Feddes Repertorium 124: 80-97.

Doyle, J.A. 2008. Integrating molecular phylogenetic and paleobotanical evidence on origin of the flower. International Journal of Plant Sciences 169: 816-843.

Doyle, J.A. 2013. Phylogenetic analyses and morphological innovations in land plants. Annual Plant Reviews 45: 1-50.

Emberger, L. 1942. Sur les Ptéridospermées et les Cordaitales. Bulletin de la Société Botanique de France 89: 202-203.

Esau, K. 1977. Anatomy of seed plants. Ed. 2. John Wiley and Sons, New York, 550 pp.

Florin, R. 1951. Evolution in cordaites and conifers. Acta Horti Bergiani 15: 285-388.

Floyd, S.K. \& J.L. Bowman 2006. Distinct developmental mechanisms reflect the independent origins of leaves in vascular plants. Current Biology 16: 1911-1917.

Forbis, T.A., S.K. Floyd \& A. de Queiroz 2002. The evolution of embryo size in angiosperms and other seed plants: implications for the evolution of seed dormancy. Evolution 56: 2112-2125.

Friedman, W.E., J.B. Bachelier \& J.I. Hormaza 2012. Embryology in Trithuria submersa (Hydatellaceae) and relationships between embryo, endosperm, and perisperm in early-diverging flowering plants. American Journal of Botany 99: 1083-1095.

Galtier, J. 2010. The origins and early evolution of the megaphyllous leaf. International Journal of Plant Sciences 171: 641-661.

Gerrienne, P., B. Meyer-Berthaud, M. Fairon-Demaret, M. Streel \& P. Steemans 2004. Runcaria, a Middle Devonian seed plant precursor. Science 306: 856-858.

Gifford, E.M. \& A.S. Foster 1989. Morphology and evolution of vascular plants, 3rd ed. W. Freeman, New York, 626 pp.

Goebel, K. 1905. Organography of plants. Authorized English edition. Part 2. Clarendon Press, Oxford. 707 pp.

Goebel, K. 1932. Organographie der Pflanzen. Aufl. 3. Fischer, Jena. $1820 \mathrm{~S}$.

Graham, L.E., M.E. Cook \& J.S. Busse 2000. The origin of plants: Body plan changes contributing to a major evolutionary radiation. Proceedings of the National Academy of Sciences, USA 97: 4535-4540.

Graham, L.K.E. \& L.W. Wilcox 2000. The origin of alternation of generations in land plants: a focus on matrotrophy and hexose transport. Philosophical Transactions of the Royal Society of London B 355: 757-767.

Graham, S.W. \& W.J.D. Iles 2009. Different gymnosperm outgroups have (mostly) congruent signal regarding the root of flowering plant phylogeny. American Journal of Botany 96: 216-227.

Groff, P.A. \& D.R. Kaplan 1988. The relation of root systems to shoot systems in vascular plants. Botanical Review 54: 387-422.

Grushvitzky, I.V. 1963. Subterranean germination and the functions of cotyledons. Botanicheskii Zhurnal 48: 906-915 (in Russian). [Грушвицкий И.В. 1963. Подземное прорастание и функции семядолей // Ботанический журнал. Т. 48, № 6. С. 906-915].

Guttenberg, H. von 1966. Histogenese der Pteridophyten. 312 S. In: Encyclopedia of plant anatomy. Traite d'Anatomie Vegetale. Ed. 2, (W. Zimmermann \& P. Ozenda, eds.), Band 7. Teil 2. Spezieller Teil.

Haccius, B. 1952. Verbreitung und Ausbildung der Einkeimblättrigkeit bei den Umbelliferen. Österreichische Botanische Zeitschrift 99: 483-505. 
Haccius, B. 1953. Histogenetische Untersuchungen an Wurzelhaube und Kotyledonarscheide geophiler Keimpflanzen (Podophyllum und Eranthis). Planta 41: 439-458.

Haines, R.W. \& K.A. Lye 1979. Monocotylar seedlings: a review of evidence supporting an origin by fusion. Botanical Journal of the Linnean Society 78: 123-140.

Harrison, C.J., S.B. Corley, E.C. Moylan, D.L. Alexander, R.W. Scotland \& J.A. Langdale 2005. Independent recruitment of a conserved developmental mechanism during leaf evolution. Nature 434: 509-514.

Hilton, J. 1998. Review of the fossil evidence for the origin and earliest evolution of the seed-plants. Acta Botanica Sinica 40: 981-987.

Hilton, J. \& R.M. Bateman 2006. Pteridosperms are the backbone of seed plant evolution. Journal of the Torrey Botanical Society 133: 119-168.

Johansson, M. \& B. Walles 1994. Functional anatomy of the ovule in broad bean (Vicia faba L.): ultrastructural seed development and nutrient pathways. Annals of Botany 74: 233-244.

Kaplan, D.R. \& T.J. Cooke 1997. Fundamental concepts in the embryogenesis of Dicotyledons: a morphological interpretation of embryo mutants. Plant Cell 9: 1903-1919.

Kenrick, P. 2002. The telome theory. In: Developmental genetics and plant evolution (Q.C.B. Cronk, R.M. Bateman \& J.A. Hawkins, eds.), pp. 365-387. Taylor \& Francis, London.

Kenrick, P. \& P.R. Crane 1997. The origin and early diversification of land plants: a cladistic study (Smithsonian Series in Comparative Evolutionary Biology). Smithsonian Institution, Washington, DC, $441 \mathrm{pp}$.

Krassilov, V.A. 1972. Mesozoic flora of the river Bureya (Ginkgoales and Czekanowskiales). Nauka, Moscow, 151 pp. (in Russian). ККасилов В.А. 1972. Мезозойская флора реки Бурея (Ginkgoales и Czekanowskiales). Москва: Наука. 151 с.].

Krassilov, V.A. 1989. Origin and early evolution of flowering plants. Nauka, Moscow, 264 pp. (in Russian). [Kpaсилов В.А. 1989. ПроисхожАение и ранняя эволюция цветковых растений. Москва: Наука. 264 с.].

Krassilov, V.A. 1997. Angiosperm origins: morphological and ecological aspects. Pensoft Publishers, Sofia, 270 pp.

Krassilov, V.A. 2009. Diversity of Mesozoic gnetophytes and the first angiosperms. Paleontological Journal 43: 1272-1280.

Ligrone, R., J.G. Duckett \& K.S. Renzaglia 1993. The gametophyte-sporophyte junction in land plants. Advances in Botanical Research 19: 231-317.

Linkies, A., K. Graebner, C. Knight \& G. Leubner-Metzger 2010. The evolution of seeds. New Phytologist 186: 817-831.

Lodkina, M.M. 1988. Evolutionary relations between monoand dicotyledons based on embryo and seedling study. Botanicheskii Zhurnal 73: 617-628 (in Russian.) [АОАКина М.M. 1988. Эволюционные отношения однодольных и Авудольных по Аанным изучения зародыша и проростков // Ботанический журнал. Т. 73, № 5. С. 617-628].

Long, A.G. 1975. Further observations on some Lower Carboniferous seeds and cupules. Transactions of the Royal Society of Edinburgh B 69: 267-293.

Lyon, H.L. 1902. The phylogeny of cotyledons. Postelsia: the yearbook of the Minnesota Seaside Station 1901: 56-86.

Mapes, G., G.W. Rothwell \& M.T. Haworth 1989. Evolution of seed dormancy. Nature 337: 645-646.

Marshall, J.E.A. \& A.R. Hemsley 2003. A Mid Devonian seed-megaspore from East Greenland and the origin of the seed plants. Palaeontology 46: 647-670.

Mathews, S. 2009. Phylogenetic relationships among seed plants: persistent questions and the limits of molecular data. American Journal of Botany 96: 228-236.
Mestre, J.-C. \& M. Guédès 1983. Nature et signification phylogénétique du cotyledon. Bulletin de la Société Botanique de France. Actualités Botaniques 130: 7-22.

Meyen, S.V. 1987. Fundamentals of palaeobotany. Chapman \& Hall, N.Y.

Meyer, K.I. 1958. Morphogeny of higher plants. Moscow University Press, Moscow, 254 pp. (in Russian). [Мейер К.И. 1958. Морфогения высших растений. Москва: ИзАательство Московского университета. 254 с.].

Niklas, K.J. 2008. Embryo morphology and seedling evolution. In: Seedling ecology and evolution (M.A. Leck, V.T. Parker \& R.L. Simpson, eds.), pp. 103-129, Cambridge University Press, Cambridge.

Niklas, K.J. \& U. Kutschera 2009. The evolutionary development of plant body plans. Functional Plant Biology 36: 682-695.

Pant, D.D. \& D.D. Nautiyal 1987. Diphyllopteris verticillata Srivastava, the probable seedling of Glossopteris from the Palaeozoic of India. Review of Palaeobotany and Palynology 51: 31-36.

Pearson, H.H.W. 1929. Gnetales. Cambridge University Press, Cambridge, 194 pp.

Pettitt, J.M. \& C.B. Beck 1968. Archaeosperma arnoldii - a cupulate seed from the Upper Devonian of North America. Contributions from the Museum of Paleontology, the University of Michigan 22: 139-154.

Prestianni, C. \& P. Gerrienne 2010. Early seed plant radiation: an ecological hypothesis. Geological Society, London, Special Publications 33: 71-80.

Raven, J.E. 1999. The minimum size of seeds and spores in relation to the ontogeny of homoiohydric plants. Functional Ecology 13: 5-14.

Rothwell, G.W. \& S.E. Scheckler 1988. Biology of ancestral gymnosperms. In: Origin and evolution of the gymnosperms (C.B. Beck, ed.), pp. 85-134, Columbia University Press, New York.

Rothwell, G.W., S.E. Scheckler \& W.H. Gillespie 1989. Elkinsia gen. nov., a Late Devonian gymnosperm with cupulate ovules. Botanical Gazette 150: 170-189.

Rudall, P.J. \& R.M. Bateman 2007. Developmental bases for key innovations in the seed-plant microgametophyte. Trends in Plant Science 12: 317-326.

Rydin, C., B. Mohr \& E.M. Friis 2003. Cratonia cotyledon gen. et sp. nov.: a unique Cretaceous seedling related to Welwitschia. Proceedings of the Royal Society of London B (Suppl.) 270: S29-S32.

Sachs, J. 1863. Über die Keimung des Samens von Allium cepa. Botanische Zeitung 21: 57-62, 65-70.

Sanders, H., G.W. Rothwell \& S.E. Wyatt 2009. Morphological alterations in the evolution of leaves. International Journal of Plant Sciences 170: 860-868.

Scatizzi, A. 1937. Ricerche sulla germinazione di Ephedra altissima. Nuovo Giornale botanico italiano (Nuova serie) 44: 345-375.

Schneckenburger, S. 1993. Embryology and germination in gymnosperms. Academia Nacional De Ciencias (Córdoba, Argentina). Miscelanea 91: 1-22.

Seward, A.C. \& S.O. Ford 1906. The Araucarieae, recent and extinct. Philosophical Transactions of the Royal Society of London, B 198: 305-411.

Siegert, A. 1989. Zur Phylogenie der Wurzel. Teil 1. Die Radicula. Koeltz Scientific Books, Königstein. 105 S.

Sokoloff, D.D., M.V. Remizowa, A.S. Beer, S.R. Yadav, T.D. Macfarlane, M.M. Ramsay \& P.J. Rudall 2013. Impact of spatial constraints during seed germination on the 
evolution of angiosperm cotyledons: a case study from tropical Hydatellaceae (Nymphaeales). American Journal of Botany 100: 824-843.

Sokoloff, D.D., M.V. Remizowa, J.G. Conran, T.D. Macfarlane, M.M. Ramsay \& P.J. Rudall 2014. Embryo and seedling morphology in Trithuria lanterna (Hydatellaceae, Nymphaeales): new data for infrafamilial systematics and a novel type of syncotyly. Botanical Journal of the Linnean Society 174: 551-573.

Spurr, A.R. 1949. Histogenesis and organization of the embryo in Pinus strobus L. American Journal of Botany 36: 629-641.

Stidd, B.M. \& K. Cosentino 1976. Nucellangium: gametophytic structure and relationship to cordaites. Botanical Gazette 137: 242-249.

Stockey, R.A. 1975. Seeds and embryos of Araucaria mirabilis. American Journal of Botany 62: 856-868.

Stockey, R.A. 1977. Reproductive biology of the Cerro Cuadrado (Jurassic) fossil conifers: Pararancaria patagonica. American Journal of Botany 64: 733-744.

Stockey, R.A. \& T.N. Taylor 1978. On the structure and evolutionary relationships of the Cerro Cuadrado fossil conifer seedlings. Botanical Journal of the Linnean Society 76: 161-176.

Takhtajan, A. 1991. Evolutionary trends in flowering plants. Columbia University Press, New York, 241 pp.

Taylor T.N., E.L. Taylor \& M. Krings 2009. Paleobotany: the biology and evolution of fossil plants. Elsevier, Amsterdam. $1230 \mathrm{pp}$.

Tillich, H.-J. 1990. Die Keimpflanzen der Nymphaeaceae monocotyl oder dicotyl? Flora 184: 169-176.

Tillich, H.-J. 1995. Seedlings and systematics in monocotyledons. In: Monocotyledons: systematics and evolution (P.J. Rudall, P.J. Cribb, D.F. Cutler \& C.J. Humphries, eds.), pp. 303-352. Royal Botanic Gardens, Kew.

Tillich, H.-J. 2007. Seedling diversity and the homologies of seedling organs in the order Poales (Monocotyledons). Annals of Botany 100: 1413-1429.
'Timonin, A.C. 1989. On the root lateral branching. Bulleten' Moskouskogo obshchestva ispytatelei prirody. Otdel biol. 94(6): 38-48 (in Russian). [Тимонин А.К. 1989. О боковом ветвлении корней // Бюлметень МОИП. ОтАец биол. Т. 94, № 6. С. 38-48].

Titova, G.E. 2006. Variations in cotyledon apparatus development. In: Embryology of flowering plants: Terminology and concepts, vol. 2, Seed, (T.B. Batygina, ed.), pp. 230-258, Science Publishers, Enfield \& Plymouth.

Tzvelev, N.N. 2000. Embryos of Magnoliophyta as primary phytomers. Bulleten' Moskovskogo obshchestva ispytatelei prirody. Otdel biol. 105(4): 60-64 (in Russian). [велев Н.Н. 2000. Зародыши семян покрытосеменных растений (Magnoliophyta) как первичные фитомеры // Бюлметень МОИП. ОтАел биол. Т. 105, вып. 4. С. 60-64].

Tomescu, A.M.F. 2009. Megaphylls, microphylls and the evolution of leaf development. Trends in Plant Science 14: 5-12.

Troll, W. 1943. Vergleichende Morphologie der höheren Pflanz̧en. Band 1. Teil 3. Borntraeger, Berlin.

Vasilchenko, I.T. 1937. A remarkable case of seed germination in Ephedra ciliata C.A.M. Priroda 26(3): 95-97 (in Russian). [Васильченко И.Т. 1937. Замечательный случай прорастания семян эфедры (Ephedra ciliata C.A.M.) // Природа. № 3. С. 95-97].

Vasilchenko, I.T. 1960. Seedlings of trees and shrubs (a manual). Izdatel'stvo Akademii nauk SSSR, Moscow, Leningrad, 302 рр. (in Russian). [Васильченко И.Т. 1960. Всходы деревьев и кустарников. Определитель. М.; $\Lambda .:$ Издательство Академии наук СССР. 302 с.].

Ye, N.-G., G.-Q. Gou, H.-M. Liao \& Z.-L. Zhang 1993. The seedling types of gymnosperms and their evolutionary relationships. Acta Phytotaxonomica Sinica 31: 505-516.

Zhou, Z.-Y. 2009. An overview of fossil Ginkgoales. Palaeoworld 18: 1-22.

\section{Margarita Remizowa \& Dmitry Sokoloff:}

Valentin Abramovich Krassilov was a great scientist and original thinker whose works and ideas covered a remarkably broad scope of scientific disciplines. The ideas of Professor Krassilov were sometimes provocative and often did not fit common paradigms of contemporary science. Either accepting or criticising him we had to learn a lot from him. For example, it was a stimulating shock to attend one of his lectures on plant-arthropod interactions where he highlighted a significance of variation in leaf margin as possible adaptation against herbivorous insects. We had a great pleasure and honour of meeting Valentin Krassilov several times in Moscow and visiting him twice in Israel. Due to the courtesy and hospitality of Valentin Krassilov and Sophia Barinova, we had an opportunity of seeing so many places in Israel and realising the beauty of this country. We will never forget the days spent during these visits, discussions and conflicting interpretations of the problematic plant Cercidiphyllum and its fossil relatives - as well as many topics not related to botany or science. 